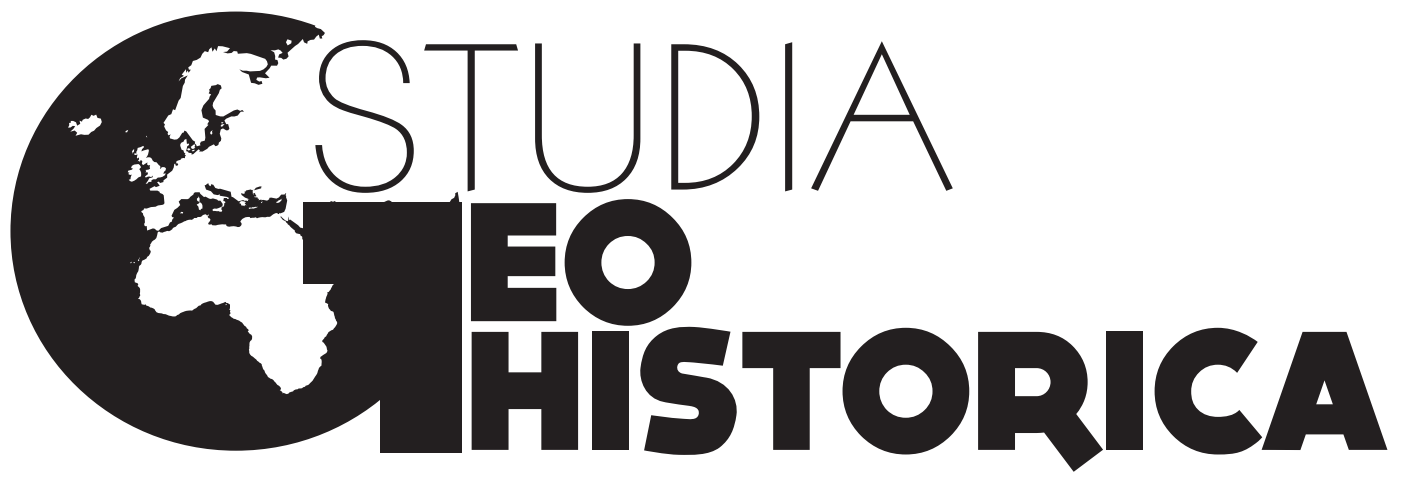

NR 06|2018 ROCZNIK HISTORYCZNO-GEOGRAFICZNY 


\section{Contents}

A note from the editors 5

International Conference of Historical Geographers

Diogo de Carvalho Cabral

Landscape and Letterscape in Early Colonial Brazil 7

Karen M. Morin

Prisoners and Animals: An Historical Carceral Geography ... 28

Humphrey Southall

Spaces, Places, Features and Units: Web-Enabling Historical Geography. 39

\section{Articles and theses}

Agnieszka Latocha, Dominik Nowakowski

Sources and Methods Used in the Reconstruction of Settlement Networks:

An Archaeological and Geographical Perspective on the Example of Silesia

Marek Sobczyński

Polish Geographical Survey of Borders until 1945

\section{Roman Czaja}

Historical Atlas of Polish Towns. Between Source Edition

and the Cartographic Presentation of Research on the History of Towns

\section{Piotr Guzowski}

Economic Geography of Poland in the Period of Growth (14-16th Century)

in the Polish Historical Study

Dzmitry Vitsko

Historical Cartography in Belarus (Studies on the Administrative Division,

Borders and Population of the Grand Duchy of Lithuania)

Henryk Rutkowski

A Few Comments on the Historical Borders in Poland

Bogumił Szady

Historical Cartography of Confessions and Religions in the Polish-Lithuanian

Commonwealth: Between Historical Geography and Spatial History 136 


\section{Tomasz Figlus}

The Past and Present of Historical Morphology of Rural and Urban Forms in Poland

\section{Maryana Dolynska}

Some Principles of Interdisciplinary Investigation

for Recreating the Historical Topography of Urban Spaces

\section{Atlas Fontium}

Atlas Fontium

(Marek Stoń)

Tomasz Panecki, Tomasz Związek, Grzegorz Myrda

The Spatial Database Development for Research on Settlements and Afforestation in Nowy Tomyśl Plain in Early Modern Times

Marek Słoń, Urszula Zachara-Związek (eds.)

The Court Records of Wschowa (1495-1526). Digital Edition

\section{Reviews and discussions}

Deutscher Historischer Städteatlas, Nr. 5: Dortmund, Hrsg. Peter Johanek, Jürgen Lafrenz, Thomas Tippach, Münster 2018 (Michał Stomski) 


\title{
Prisoners and Animals: An Historical Carceral Geography
}

\author{
Karen M. Morin
}

\section{Introduction ${ }^{*}$}

My new book, Carceral Space, Prisoners and Animals (2018), hinges together two distinct areas of research, carceral geography and critical animal studies, with an overall aim to make connections between mass incarceration of humans and mass exploitation of nonhuman animals in the U.S. today. These processes are connected, and thus in the book I propose an analysis of "the carceral" from a broader vantage point than has yet been done, developing a "trans-species carceral geography" that includes spaces of nonhuman captivity, confinement, and enclosure alongside that of the human. The linkages across prisoner and animal carcerality that I place into conversation draw from a number of institutional domains, based on their form, operation, and effect. These institutional domains include the prison death row/execution chamber and the animal slaughterhouse; sites of laboratory testing of pharmaceutical and other products on incarcerated humans and captive animals; sites of exploited prisoner and animal labor; and the prison solitary confinement cell and the zoo cage. The ways that humans and nonhumans can be made disposable and killable in the prison and slaughterhouse; can be exploited for entertainment or as experimental research material; and whose bodies and labor can be made into property and commodity; are not the same at these sites, but they share key aspects.

\footnotetext{
* This text of this essay and lecture to be presented at the $17^{\text {th }}$ International Conference of Historical Geographers in Warsaw, Poland, is excerpted from my recently released book: K.M. Morin, Carceral Space, Prisoners and Animals, London 2018.
}

Cross-pollinating carceral geography and critical animal studies offers an opportunity to reflect not only on the ways in which industrial violence against humans and nonhuman animals has been naturalized and made possible, but also the ways in which these everyday regimes of violence have been produced and are maintained together - they have been enmeshed and entangled in similar processes, co-constituted and co-articulating in their basic carceral logics. My focus is on the geographies of these sites (locations, design, and layout); the highly regulated technologies and movements within them; the emotional and psychological strain enacted via daily operations; the legal contexts within which these industries are (or are not) regulated; and the ways in which "animalization" of certain bodies works to create the conditions for their exploitation and disposability. These are not particularly new ideas, but I offer a novel synthesis and application of them. In that sense the book is more conceptual than it is theoretical, in that I engage some of the current themes, arguments, and activist scholarship of carceral geography and critical animal studies - to broker between these ideas and literatures, to bring them into conversation.

Development of the prison-, agricultural-, medical-, and entertainment-industrial complexes followed different historical-geographical trajectories towards their present iterations. My project is not in specifically comparing these developmental trajectories - governmental regulations or deregulations of industrial processes, legal maneuverings that served 
to protect, enrich, and incentivize certain practices, architectural or technological advances, or so on. Nonetheless a number of historical-geographical developments and processes cannot go without notice such as the rise of the prison industry that in many ways stepped in to fill the economic void created in many communities by deregulation of factory-scale farming. More to my project, though, are what these industries collectively produced over the past few decades: unprecedented numbers of confined bodies subjected to unprecedented levels of violence within the industrial U.S. today.

\section{A personal and professional journey}

Writing Carceral Space, Prisoners and Animals was quite a personal journey. I first became interested in prison studies as an activist - as a volunteer and decade-long executive board member of a local nonprofit prisoner rights group called the Lewisburg Prison Project. The Project's focus is on protecting prisoners' civil rights while incarcerated in prisons located in my state of Pennsylvania. Where I live in Pennsylvania has unfortunately one of the highest concentrations of correctional facilities anywhere in the U.S. and prisons are the second largest industry in Pennsylvania overall. Inspired by my association with this group, my work in recent years has become more scholarly-activist in nature. I have worked on a number of projects related to the "spatial violence" of U.S. prisons, and this includes an historical-geographical study of USP-Lewisburg, the U.S. federal penitentiary located in my town that has unfortunately become the focus of much of our organization's current work due to its uniquely torturous "special management unit" for federal prisoners ${ }^{1}$. I also co-edited a book with Dr. Dominique

\footnotetext{
1 K.M. Morin, "Security Here Is Not Safe": Violence, Punishment, \& Space in the Contemporary U.S. Penitentiary, "Environment and Planning D: Society and Space", 31 (3), 2013, p. 381-399.
}

Moran, Historical Geographies of Prisons: Unlocking the Usable Carceral Past which readers may find of interest ${ }^{2}$. This is the first volume of its kind to take a comprehensive historical-geographical approach to the study of correctional institutions as a specific subset of the new, fast-moving, and fast-developing subfield of carceral geography. The book examines, analyzes, and critiques practices of incarceration, regimes of punishment, and their corresponding institutional spaces, with the overall aim of helping us to understand their legacies in the present. The breadth of the work collected spans the $18^{\text {th }}$ through $21^{\text {st }}$ centuries, and takes a correspondingly wide geographical reach across sites in North America, Europe, Asia, and Latin America.

My work on prisons continued, though it was not until a visit to New York's Bronx Zoo celebrating my daughter's birthday a few years ago that the ideas for my recent book project began to take shape. Watching the crowds of tourists, most but not all of them children, jump up and down and pound the glass wall of one particular Amur tiger's cage struck me in ways that trips to zoos had not in the past: while the beautiful creature paced anxiously around and around a big rock in its small enclosure, the notion of a trans-species carceral geography really clicked in.

Disciplinarily, although I consider myself first and foremost an historical geographer, my new book is not an historical-geography of the sites I study - the prison, the slaughterhouse, the research lab, the zoo, and the farm. Rather, the book is an attempt to uncover the epistemic violence that pervades contemporary industrial America yet is normalized and "neutralized" in countless ways in everyday life. And yet, I would also make the

\footnotetext{
2 Historical Geographies of Prisons: Unlocking the Usable Carceral Past, ed. K.M. Morin, D. Moran, London 2015.
} 
case that I could not have written this book without a fully developed historical geographical sensibility, imagination, and skill set. So I suppose my overall rather simple assertion about my methodology is that I could not have accomplished this work without an appreciation, an understanding, a mindset of an historical geographer. So by way of an example, in what follows I illustrate how the pivotal points of my study rely foundationally on historical geographical thinking. The first is to highlight one of the facets of the "carceral logic" that is shared across the industries I study - that is, the ideological and ontological status of "the human" and "the animal".

\section{Carceral logic: The human and the animal}

Key to my thesis throughout Carceral Space, Prisoner and Animals is that the distinctions between "the human" and "the animal" themselves are made through encounters with carceral spaces. Which humans and nonhumans have the force of legal, political, cultural, or other protections due to their special "human" qualities, and which fall outside of those protections as "animal"? The process of "animalization" in particular subjugates both certain humans and certain nonhumans into hierarchies of worthiness and value. Fundamental to how and why certain humans (prisoners) and certain species of animals can be exploited, objectified, or made killable within the prison, the farm, the research lab, or the zoo is the social construction of the human/nonhuman divide itself - the social meanings that attach to various bodies and populations.

The hierarchies that these distinctions perpetuate are based on a number of social markers. Racial difference is foundational, for example, to much of the "criminal as animal" rhetoric, particularly via animalistic representations of Black men who disproportionately comprise the U.S. prison population as well as those on death row (below) ${ }^{3}$. Meanwhile certain animals such as pets can be anthropomorphized and "humanized" while others - vermin, pests, livestock - remain "animalized". Many processes are in play that either amplify the status of certain humans and nonhumans, or reduce the status of others. These have different and important implications - not least of which are the processes that govern how certain lives can be made disposable and killable because they lack ostensibly human qualities. "The human", though, is itself a highly contested category, from which many human lives have been and continue to be excluded. And indeed, perhaps in Western societies at least, it has only been the White, western, bourgeois man who has, across space and time, occupied or been imputed the status of "complete" human".

Dozens of scholars have offered useful historical-geographical illustrations of the many human groups that have been vilified as animal or "subhuman other", marking countless numbers of dominations, exploitations, and oppressions ${ }^{5}$. Animalization of various human groups, vilified

3 L.M. Cacho, Social Death: Racialized Rightlessness and the Criminalization of the Unprotected, New York 2012; C.J. Kim, Dangerous Crossings: Race, Species, and Nature in a Multicultural Age, Cambridge 2015; M. Alexander, The New Jim Crow: Mass Incarceration in the Age of Colorblindness, New York 2012; L. Wacquant, "Deadly Symbiosis": When Ghetto and Prison Meet and Mesh, in: Mass Imprisonment: Social Causes and Relations, ed. D. Garland, London 2001, p. 293-304; "Death Penalty Information Center" (http://www.deathpenaltyinfo.org/death-row-inmatesstate-and-size-death-row-year, access: December 2017).

$4 \mathrm{~S}$. Wynter, Unsettling the Coloniality of Being/Power/Truth/Freedom: Toward the Human, After Man, Its Overrepresentation - An Argument, "CR: The New Centennial Review", 3 (3), 2003, p. 257-337; Z.I. Jackson, Outer Worlds: The Persistence of Race in Movement "Beyond the Human", "Journal of Lesbian and Gay Studies", 21 (2-3), 2015, p. 215-218; Ko Syl, Notes from the Border of the Human-Animal Divide: Thinking and Talking about Animal Oppression When You're Not Quite Human Yourself, in: Aphro-ism: Essays on Pop Culture, Feminism, and Black Veganism from Two Sisters (https://aphro-ism.com/, access: January 13, 2016).

5 These include, among many others: C. Patterson, Eternal Treblinka: Our Treatment of Animals and the Holocaust, New York 2002, p. 27-50; C.J. Kim, Dangerous Crossings, p. 24-60; M.H. Glick, Animal Instincts: Race, Criminality, and the Reversal of the "Human", "American Quarterly", 65 (3), 2013, p. 639-659; H.J. Nast, Pit Bulls, Slavery, and Whiteness in the Mid- to Late-Nineteenth Century U.S.: Geographical Trajectories; Primary Sources, in: Critical Animal Geographies: Politics, Intersections, and Hierarchies in a Multispecies World, ed. K. Gillespie, 
as beasts, brutes, and apes, to pigs, rats, and vermin, has played a central role in enslavements, genocides, colonizations, and imperialisms across centuries and continents. Humans across space and time have been held captive, displayed, and made into animal spectacles. For example, it was common in $19^{\text {th }}$ century American (and European) geographical circles for returning explorers to publicly parade indigenous peoples captured from the Arctic or Africa as living, subhuman "discoveries" within the Empire-building enterprise. The "human zoo" at the 1906 Bronx Zoo Monkey House in the U.S. illustrates an important case in point. A visitor there could see Ota Benga, a member of the (Congolese) Batwa people, displayed in a cage with an orangutan. The sign above the cage listed Benga's age, height, and weight. It also read: "Brought from the Kasai River, Congo Free State, South Central Africa by Dr. Samuel P. Verner. Exhibited each afternoon during September"6.

Without rehearsing the vast number or extent of such examples here, a brief overview of American wars and interventions abroad in the last century reveals dominant cultural representations of Philippino "yellow monkeys" (1898), Vietnamese "termites" (1969), and Iraqi "cockroaches" (1991), to name just a few. Within the U.S., African-Americans, Native-Americans, and Chinese-Americans have been targeted as the most animal of humans by the dominant culture - base, lowly, brutish, irrational, vicious, dirty, or lustful - so as to justify their subordination, exploitation, and extermination. Claire Jean $\mathrm{Kim}^{7}$ argues that such associa-

R.-C. Collard, London 2015, p. 127-145; W.D. Hart, Slaves, Fetuses, and Animals: Race and Ethical Rhetoric, "Journal of Religious Ethics", 42 (4), 2014, p. 661-690.

6 P. Newkirk, Spectacle: The Astonishing Life of Ota Benga, New York 2015. 7 C.J. Kim, Dangerous Crossings, p. 24-60; idem, Moral Extensionism or Racist Exploitation: The Use of Holocaust and Slavery Analogies in the Animal Liberation Movement, "New Political Science", 33 (3), 2011, p. 311-333. tions first converged in a powerful way ca. 1860 when the Black, Native, and Chinese "questions" arose in U.S. national consciousness. Within various contexts these groups came to occupy a marginalized borderland between human and animal. Their uses of and relationships to nonhuman animals - for example in San Francisco Chinatown's live animal markets - amplified accusations of cruelty and barbarism of these groups and corresponding racism, nativism, and cultural imperialist responses. Maneesah Deckha has shown that the "discourse of civilization" itself permeates animal anti-cruelty legislation, targeting practices of minoritized groups' behavior toward animals as deviant or transgressive and thereby reinforcing race, class, religious, and gender hierarchies. Such legislation targets individual animal abusers who, through gross neglect, do not maintain adequate shelter, food, or veterinary care for animals. Yet meanwhile, industrial practices that abuse animals on a whole other (massive) scale remain immune from prosecution. This has the double effect of both selecting certain animals for non-protection ("animalized animals") as well as creating a deviant class of "animalized humans"

In the next section I provide one potent example of industrial practices that rely foundationally on the carceral logic of animalization just described. In this discussion I turn my attention to the spatial logic of "assembly line killing" evident in the prison's death row and the animal slaughterhouse.

\section{Death row across species}

It is hard to miss the parallels in the rise and development of the agricultural industrial complex and that of the prison industrial complex in the United States in the last half century. Both of these

\footnotetext{
8 M. Deckha, Welfarist and Imperial: The Contributions of Anticruelty Laws to Civilizational Discourse, "American Quarterly", 65 (3), 2013, p. 515548.
} 
industries rapidly expanded during the 1970s and 1980s era of deregulated "big agriculture" on the one side, and changes in drug and sentencing laws that led to new thresholds in mass incarceration on the other - with an unprecedented 2.4 million people behind bars in the peak year of 2014. The parallel rise in mass incarceration and retention and expansion of the death penalty are indicative of an historical "hearty American appetite for punitiveness" that is exceptional among western nations. After the temporary abolition of capital punishment in 1972, the death penalty "came back with a vengeance" in the years following its reinstatement by the U.S. Supreme Court in 1976. By the late 1990s, death sentencing rates and execution rates reached highs that the U.S. had not seen in 50 years, with the Supreme Court leaving the legalities of capital punishment up to individual states. Since 1976 there have been 1,442 state-sponsored executions 9 .

Today, capital punishment is legal in 32 states, while 18 have abolished it. There are 36 prisons in the U.S. with a "death row" and at the latest count these prisons held 2,905 people awaiting execution 42 percent of whom are Black, 42 percent White, 13 percent Hispanic, and 3 percent "other". Clearly these percentages indicate the uneven and racialized application of the capital sentence considering that, for example, Black people comprise 34.7 percent of those executed in the U.S. since 1976, and 42 percent of those on death row, yet comprise only 13.2 percent of the U.S. population. Most death row prisoners await execution by lethal injection, notwithstanding numerous recent

\footnotetext{
9 M. Alexander, The New Jim Crow; M. Gottschalk, The Prison and the Gallows: The Politics of Mass Incarceration in America, Cambridge 2006; C.S. Steiker, J.M. Steiker, The Death Penalty and Mass Incarceration: Convergences and Divergences, "American Journal of Criminal Law", April 1, 2014; D. Garland, Capital Punishment and American Culture, "Punishment \& Society", 7 (4), 2005, p. 347-376; J.A. Tyner, A.R. Colucci, Bare Life, Dead Labor, and Capital(ist) Punishment, "ACME: An International Journal for Critical Geography", 14 (4), 2015, p. 1083-1099.
}

"botched" executions, drug shortages, and states seeking alternatives ${ }^{10}$.

Prisoners sentenced to death typically spend over a decade awaiting execution, some for over 20 years or more due to lengthy appeals processes. They spend 23 or 24 hours a day alone in their cells, living with the constant anxiety of impending death. As the execution date approaches they spend up to two weeks in a separate "death watch" cell near the execution chamber itself. Not surprisingly, they suffer high rates of mental illness, what some have termed the "death row syndrome", which would of course be in addition to the mental illnesses caused by solitary confinement in and of itself. Much debate surrounds the practice of capital punishment, including those about its underlying racial disparities, controversial methods of killing, inconsistent and arbitrary patterns across state lines (with the South disproportionately represented), its (lack of) efficacy in deterring crime, its cost, and of course its basic (im)morality. The issue of secrecy surrounding the execution chamber is another, with only a tiny number of court-approved spectators allowed to witness the killings ${ }^{11}$.

As Thomas and Shields observe, "state-sanctioned killings are capital punishment in one arena and "processing" in another"; they intersect with a concern for "human and animal's $[s i c]$ lived experiences" 12 .

\footnotetext{
10 "Death Penalty Information Center" (http://www.deathpenaltyinfo.org/ death-row-inmates-state-and-size-death-row-year, access: December 2017).

11 L. Guenther, Solitary Confinement: Social Death and Its Afterlives, Minneapolis 2013; C. Haney, A Culture of Harm: Taming the Dynamics of Cruetty in Supermax Prisons, "Criminal Justice and Behavior", 35, 2008, p. 956984; M.D. Cunningham, M.P. Vigen, Death Row Inmate Characteristics, Adjustment, and Confinement, "Behavioral Sciences and the Law", 20, 2002, p. 191-210; L. Rhodes, Supermax Prisons and the Trajectory of Exception, "Studies in Law, Politics, and Society", 47, 2009, p. 193-218; Writing for Their Lives: Death Row USA, ed. M. Mulvey-Roberts, Urbana 2007.

12 S. Thomas, L. Shields, Prison Studies and Critical Animal Studies: Understanding Interconnectedness beyond Institutional Comparisons, "Journal for Critical Animal Studies", 10, 2012, p. 4-11; quote on p. 4.
} 


\section{Entangled experiences: The slaughterhouse}

Historical geographies of the animal slaughterhouse are instructive reminders of the origin of the $19^{\text {th }}$ century cattle towns that fed Chicago's Union Stock yards in the 1850 s and 1860 s, setting the stage for today's meatpacking industry ${ }^{13}$. Patterson describes the enormous complex of hotels, restaurants, saloons, offices, and "an interlocking system of 2,300 connected livestock pens" that took up more than a square mile in southwestern Chicago. At the time, the meat companies Amour and Swift each employed more than 5,000 workers within those yards. By 1886 , more than 100 miles of railroad tracks surrounded the yards, and each day trains with new refrigeration capability unloaded hundreds of cars full of western longhorn cattle, sheep, and pigs. This first "mass production industry" introduced the conveyor belts, suspension hooks, scraping and skinning machines, and other technologies to increase speed and efficiency and by 1900, 400 million livestock were slaughtered annually. Today, U.S. slaughterhouses kill that number of animals in less than two weeks ${ }^{14}$.

As in the prison, the day-to-day embodied experience of captivity; of being identified with a number, a tattoo, a brand, and other forms of bodily modifications; the strain of knowing the approach of death or of the stunning apparatus or whip; all are interwoven into the day-to-day carceral space of the animal slaughterhouse. Today, approximately 10 billion land animals are held captive, mutilated, and killed in the U.S. meat-producing industry each year (nine billion of them chickens), and this figure does not include

13 C. Patterson, Eternal Treblinka; J. Rifkin, Beyond Beef: The Rise and Fall of the Cattle Culture, New York 1992; J.M. Coetzee, The Lives of Animals, Princeton 1999.

14 J. Rifkin, Beyond Beef; C. Patterson, Eternal Treblinka, p. 57-64; T. Pachirat, Every Twelve Seconds: Industrialized Slaughter and the Politics of Sight, New Haven 2011; S. Giedion, Mechanization Takes Command: A Contribution to Anonymous History, New York 1948, p. 213-246 (rpt. Minneapolis 2013). the billions more sea creatures which are counted not per animal but by weight (by the ton). These billions of cows, pigs, horses, chickens, sheep, and other farm animals herded to and through the auction block, the slaughterhouse, and other processing facilities are a basic feature of today's agribusiness industry. Industrialized food production is where, by far, the most violence towards animals occurs.

\section{Space, technology, and control}

Numerous examples of the symbolic relationship between the violence of prison torture and execution and the animal slaughterhouse can be found, such as Brower illustrating via images from the notorious Abu Ghraib prison in Iraq where prisoners were physically handled and photographed as animals to be slaughtered. Guards used blades to cut away prisoners' jumpsuits, from their necks to their thighs, branding prisoners like cattle, drawing words and symbols on their legs and buttocks, and forcing them to crawl like dogs on their hands and knees, to bark on command, and to follow their captors on leashes or strings ${ }^{15}$. These symbolic referents provide powerful insights into the relationships of violence across the prison industrial complex and the agricultural industrial complex. They provide a useful springboard to the material geographies of these sites and the ways that systematic violence in them is carried out, through their shared structural designs and disciplinary technologies and practices, they terrorize animal and human bodies in similar ways. The material geographies of the prison execution chamber and the animal slaughterhouse especially map uncannily well onto one another - their locations; their physical structures, spatial layout and design; as well as their technological and other

15 C.H. Brower, The Lives of Animals, the Lives of Prisoners, and the Revelations of Abu Ghraib, "Journal of International Law", 37, 2004, p. 13531388. 
control features that regulate movements within them.

Most obviously, these carceral sites are "hidden in plain view" in rural or remote locations, their architectures so innocuous and ordinary that they do not attract attention. From an aerial view, the prison and the slaughterhouse look the same. Timothy Pachirat discusses the "banal insidiousness" of the slaughterhouse that hides in plain sight, its construction blending physically into the landscape of "Everyplace USA"16. Sites of capital punishment today also inhabit a set of insidious visual banalities, at least in comparison to the past. The last U.S. public execution occurred in 1936. Once ritual executions were moved from the public square, the public spectacle of death shifted to the sterile courtroom, where the suffering of victims and judicial process became the important ceremonial stage of punishment. In this way the infliction of punishment shifted to the imposition of the death sentence in court proceedings. Thus the loud, unruly, festive spectacles of public execution were replaced by executions carried out in the private space of the jail or prison $\operatorname{yard}^{17}$.

At carceral sites and institutions, the killing itself is divided into stages, highly segregated by task and out of sight of one another, including from the workers themselves. Industrialized "killing centers" have several things in common: their technologies, speed, efficiency, and "rational", scientific-management assembly line techniques. Humans have been confining and killing each other and animals for millennia, but the specialization

16 T. Pachirat, Every Twelve Seconds, p. 23; R.M. Merritt, S. Hurley, Invisible Geographies: Violence and Oppression in the Prison-Industrial Complex and Concentrated Animal Feeding Operations (paper presented at the 2014 Annual Association of American Geographers Meeting, Tampa, Florida).

17 M. Gottschalk, The Prison, p. 199-203; M. Lynch, The Disposal of Inmate \#85271: Notes on a Routine Execution, "Studies in Law, Politics, and Society", 20, 2000, p. 3-34. and mass-production characteristic of the modern industrial era - the "mechanization of death" - was something new and perfected by the late $19^{\text {th }}$ century. Within these spaces are routine, mechanical, predictable, repetitive, and programmed practices. As Patterson argues, "just the right mix of deception, intimidation, physical force, and speed is needed to minimize the chance of panic or resistance that will disrupt the process" 18 . Controlled containment and controlled mobility are integral to the functioning of the slaughterhouse, as they are equipped with an array of chutes, pens, ramps and mobile shackle lines, electric prods, and mechanical hoists intended to efficiently and quickly move animals for processing.

In the prison's death row and execution chamber, each movement is carefully choreographed, regulated, and surveilled. Several authors describe the "execution assembly line" of the prison's death house and execution chamber ${ }^{19}$. Prisoners remain in their regular death row cell until two weeks prior to execution, then are moved to a specially designed "death watch" cell close to the execution chamber. Here the minute details of the condemned's final weeks in isolation are tracked; closed circuit TV and computer tracking systems open cell doors, control lights, and maintain an activity $\log$ of every movement and location of the prisoner within the death house cell. Executions were ostensibly to become swifter, painless, and more efficient with advancements in "modern" killing

18 T. Pachirat, Every Twelve Seconds, p. 44-59; C. Patterson, Eternal Treblinka, p. 110-131 (quote on p. 110); S. Giedion, Mechanization, p. 240241; M.H. Glick, Animal Instincts; M. Higgin, A. Evans, M. Miele, A Good Kill: Socio-Technical Organisation of Farm Animal Slaughter, in: Humans and Other Animals: Critical Perspectives, ed. B. Carter, N. Charles, Basingstoke 2011, p. 173-194; E. Schlosser, Fast Food Nation: The Dark Side of the All-American Meal, New York 2001, p. 172.

19 For example: M. Lynch, Disposal, p. 15; Writing for Their Lives, p. 126 130; L.K. Gillespie, Inside the Death Chamber: Exploring Executions, Boston 2003. 
technologies - historically shifting from hanging, to the firing squad, gas chamber, electric chair, to today's lethal injection. In the execution chamber itself, specific tasks are delegated to each member of the execution team, including the final enunciation - "go ahead" - of the warden. As noted by a guard assisting with a lethal injection at Huntsville, Texas, "Usually within about twenty seconds he's completely strapped down. Twenty to thirty seconds. I mean, it's down to a fine art" ${ }^{\prime 20}$.

Many scholars have shown how the design and production methods of the slaughterhouse were the precursor to assembly line production itself, including that aimed at killing humans. Giedion's re-issued Mechanization Takes Command ${ }^{21}$ usefully outlines the historical roots and social impacts of European and U.S. "scientific management" and mechanization of work, and illustrating the deep connections between the Cincinnati and Chicago slaughterhouse technologies with Henry Ford's mass production of automobiles, 1918-1939. Moreover, the industrialization of animal slaughter - their technologies, speed, efficiency, and assembly line techniques - inspired Henry Ford in automobile production and in turn, as many have argued, paved the way for the slaughter of humans in the Holocaust: "the road to Auschwitz begins at the slaughterhouse" (and in fact some of the soldiers who worked in the death camps first worked in slaughterhouses). As J.M. Coetzee's protagonist Elizabeth Costello declares in his acclaimed novel The Lives of Animals, "Chicago showed us the way; it was from the Chicago stockyards that the Nazis learned how to process bodies". The industrialized killing at the Chicago stockyards as well as Henry Ford's automobile assembly line production in-

\footnotetext{
20 Excerpted from Witness to an Execution (https://storycorps.org/listen/witness-to-an-execution/, access: June 10, 2018).

21 S. Giedion, Mechanization.
}

formed Hitler's genocidal plans, and in fact Ford was a major backer of Hitler $^{22}$.

Yet it is also important to recognize that the U.S. "correctional" (prison) industry - i.e. the United States Department of Justice - invented the gas chamber "long before Hitler". Christianson lists the 594 U.S. prisoners executed by lethal gas from 1934-1999. Ample evidence demonstrates the deep connectivity between the slaughterhouse and the execution chamber; both their materials and technologies originated from the U.S. military industrial complex of World War I, and later developing into a United States and Third Reich collaboration. U.S. scientists developed the scientific, legal, and ethical rationale for the lethal gas chamber, and U.S. firms partnered with German corporations that provided the gas. Ultimately the U.S. federal government patented two models from Eaton Metal Products of Denver and Salt Lake City, ca. 1939, which became the world's leading designer and maker of gas chambers for prison executions. Earl C. Liston's Patent Application, $\# 2,172,168$, was actually a "double-seater" gas chamber. The patent illustrates the manner by which a mechanical device drops the cyanide pellets into a chamber, a process that "provides a neat, compact mechanism which will humanely execute the criminal or criminals with the least possible delay or confusion" 23 .

While arguments in support of constructing and patenting the lethal gas chamber focused on it as a "more humane" method of killing compared with that of hanging or electrocution, as with every method of prison executions, lethal gas was eventually contested constitutionally in 1976 as cruel and inhumane. The last

\footnotetext{
22 C. Patterson, Eternal Treblinka, p. 53-110; J.M. Coetzee, The Lives, p. 72. Also see: J. Rifkin, Beyond Beef; C.J. Kim, Moral Extensionism, p. 317. For details on Ford's and Hitler's relationship see $\mathrm{S}$. Christianson, The Last Gasp: The Rise and Fall of the American Gas Chamber, Berkeley 2010, p. 86-88.

23 S. Christianson, The Last Gasp, p. 6-8, 102-120, 237-252.
} 
gas chamber execution was in Arizona in 1999. This is important to keep in mind since it is the ostensible illegitimacy of the methods of killing that have led to challenges of capital punishment, rather than the killing itself. All methods of capital punishment have been challenged juridically on the grounds of the Eighth Amendment to the Constitution's protections against cruel and unusual punishment. This includes recent challenges to today's lethal injection drug cocktail ${ }^{24}$. Perhaps the same could be said of industrial slaughter - challenges have rested on its inhumane ways of killing, not the sovereign or other right to kill itself.

\section{Concluding comment}

The aim of the above discussion and Carceral Space, Prisoners and Animals more broadly is to develop a trans-species carceral geography that offers insights into how and why the sites and spaces of human carcerality, and the endemic patterns of violence within them, share key features with sites of captivity and confinement of nonhuman animals - using the example here of sites of execution and slaughter but which would also include sites of research testing and sites of exploited entertainment and commodified labor. The above focuses specifically on some of the historical-geographical bases for the relationships drawn on in the text. Within these carceral sites a number of "carceral logics" underlie their processes and profits, including historical-geographical examples of animalization, racialization, and criminalization of certain vulnerable populations, showing how these carceral logics are foundational to their continued operation. While we might recognize almost infinite differences across the various human and nonhuman groups discussed above, these differences should not prevent us from acknowledging the entangled structures, forms, operations, and embodied experiences that developed and continue to span species' boundaries at these sites. 


\section{Bibliography}

Alexander M., The New Jim Crow: Mass Incarceration in the Age of Colorblindness, New York 2012.

Brower C.H., The Lives of Animals, the Lives of Prisoners, and the Revelations of Abu Ghraib, "Journal of International Law”, 37, 2004, p. 1353-1388.

Cacho L.M., Social Death: Racialized Rightlessness and the Criminalization of the Unprotected, New York 2012.

Christianson S., The Last Gasp: The Rise and Fall of the American Gas Chamber, Berkeley 2010.

Cunningham M.D., Vigen M.P., Death Row Inmate Characteristics, Adjustment, and Confinement, "Behavioral Sciences and the Law", 20, 2002, p. 191210.

Deckha M., Welfarist and Imperial: The Contributions of Anticruelty Laws to Civilizational Discourse, "American Quarterly", 65 (3), 2013, p. 515-548.

Garland D., Capital Punishment and American Culture, "Punishment \& Society", 7 (4), 2005, p. $347-$ 376.

Giedion S., Mechanization Takes Command: A Contribution to Anonymous History, New York 1948.

Gillespie K., Inside the Death Chamber: Exploring Executions, Boston 2003.

Glick M.H., Animal Instincts: Race, Criminality, and the Reversal of the "Human", "American Quarterly", 65 (3), 2013, p. 639-659.

Gottschalk M., The Prison and the Gallows: The Politics of Mass Incarceration in America, Cambridge 2006.

Guenther L., Solitary Confinement: Social Death and Its Afterlives, Minneapolis 2013.

Haney C., A Culture of Harm: Taming the Dynamics of Cruelty in Supermax Prisons, "Criminal Justice and Behavior", 35, 2008, p. 956-984.

Hart W.D., Slaves, Fetuses, and Animals: Race and Ethical Rhetoric, "Journal of Religious Ethics", 42 (4), 2014, p. 661-690.

Higgin M., Evans A., Miele M., A Good Kill: Socio-Technical Organisation of Farm Animal Slaughter, in: Humans and Other Animals: Critical Perspectives, ed. B. Carter, N. Charles, Basingstoke 2011, p. 173-194.

Historical Geographies of Prisons: Unlocking the Usable Carceral Past, ed. K.M. Morin, D. Moran, London 2015.

Jackson Z.I., Outer Worlds: The Persistence of Race in Movement "Beyond the Human", "Journal of Lesbian and Gay Studies", 21 (2-3), 2015, p. 215218.

Kim C.J., Dangerous Crossings: Race, Species, and Nature in a Multicultural Age, Cambridge 2015.

Kim C.J., Moral Extensionism or Racist Exploitation: The Use of Holocaust and Slavery Analogies in the
Animal Liberation Movement, "New Political Science”, 33 (3), 2011, p. 311-333.

Ko Syl, Notes from the Border of the Human-Animal Divide: Thinking and Talking about Animal Oppression When You're Not Quite Human Yourself, in: Aphro-ism: Essays on Pop Culture, Feminism, and Black Veganism from Two Sisters (https://aphro-ism.com/, access: January 13, 2016).

Lynch M., The Disposal of Inmate \#85271: Notes on a Routine Execution, "Studies in Law, Politics, and Society", 20, 2000, p. 3-34.

Merritt R.M., Hurley S., Invisible Geographies: Violence and Oppression in the Prison-Industrial Complex and Concentrated Animal Feeding Operations (paper presented at the 2014 Annual Association of American Geographers Meeting, Tampa, Florida).

Morin K.M., "Security Here Is Not Safe": Violence, Punishment, \& Space in the Contemporary U.S. Penitentiary, "Environment and Planning D: Society and Space", 31 (3), 2013, p. 381-399.

Nast H. J., Pit Bulls, Slavery, and Whiteness in the Mid- to Late-Nineteenth Century U.S.: Geographical Trajectories; Primary Sources, in: Critical Animal Geographies: Politics, Intersections, and Hierarchies in a Multispecies World, ed. K. Gillespie, R.-C. Collard, London 2015, p. 127-145.

Newkirk P., Spectacle: The Astonishing Life of Ota Benga, New York 2015.

Pachirat T., Every Twelve Seconds: Industrialized Slaughter and the Politics of Sight, New Haven 2011.

Patterson C., Eternal Treblinka: Our Treatment of Animals and the Holocaust, New York 2002, p. 27-50.

Rhodes L., Supermax Prisons and the Trajectory of Exception, "Studies in Law, Politics, and Society", 47, 2009, p. 193-218.

Rifkin J., Beyond Beef: The Rise and Fall of the Cattle Culture, New York 1992.

Schlosser E., Fast Food Nation: The Dark Side of the All-American Meal, New York 2001.

Steiker C.S., Steiker J.M., The Death Penalty and Mass Incarceration: Convergences and Divergences, "American Journal of Criminal Law", April 1, 2014.

Supreme Court Upholds Lethal Injection Procedure, "The Washington Post", June 29, 2015.

Thomas S., Shields L., Prison Studies and Critical Animal Studies: Understanding Interconnectedness beyond Institutional Comparisons, "Journal for Critical Animal Studies”, 10, 2012, p. 4-11.

Tyner J.A., Colucci A.R., Bare Life, Dead Labor, and Capital(ist) Punishment, "ACME: An International Journal for Critical Geography”, 14 (4), 2015, p. 1083-1099. 


\section{International Conference of Historical Geographers}

Wacquant L., "Deadly Symbiosis": When Ghetto and Prison Meet and Mesh, in: Mass Imprisonment: Social Causes and Relations, ed. D. Garland, London 2001, p. 293-304.

Writing for Their Lives: Death Row USA, ed. M. Mulvey-Roberts, Urbana 2007.

\section{Summary}

This paper explores some of the key historical-geographical resonances across human and nonhuman carceral geographies that appear in my book, Carceral Space, Prisoners and Animals. In it I propose a contribution to carceral geography from a broader vantage point than has yet been done, developing a "trans-species carceral geography" that includes spaces of nonhuman captivity, confinement, and enclosure alongside that of the human. The linkages across prisoner and animal
Wynter S., Unsettling the Coloniality of Being/Powerl Truth/Freedom: Toward the Human, After Man, Its Overrepresentation - An Argument, "CR: The New Centennial Review”, 3 (3), 2003, p. 257-337. carcerality that I place into conversation draw from a number of institutional and industrial domains, including the prison, the farm, the research lab, and the zoo. In this paper I specifically focus on the shared carceral logics and "animalization" of populations of humans and animals at these sites, as well as key entangled historical-geographies of the prison's death row and the animal slaughterhouse that are at once structural, operational, and technological.

Keywords: carceral geography, prisoners, animals

Karen M. Morin - Associate Provost and Professor of Geography at Bucknell University, in Pennsylvania, USA. Her books include: Women, Religion, \& Space: Global Perspectives on Gender and Faith, co-edited with Jeanne Kay Guelke (2007); Frontiers of Femininity: A New Historical Geography of the Nineteenth-Century American West (2008); Civic Discipline: Geography in America, 1860-1890 (2011); Historical Geographies of Prisons: Unlocking the Usable Carceral Past, co-edited with Dominique Moran (2015); Carceral Space, Prisoners and Animals (2018) (e-mail: morin@bucknell.edu) 